\title{
Comic Casuistry and Common Sense: Sancho Panza's Governorship
}

\author{
Michael Scham
}

\begin{abstract}
Key background to Sancho Panza's governership of Barataria (Don Quijote II. 42-53) includes the specula principum tradition, treatises on statecraft (Furió Ceriol, Ribadeneira, Castillo de Bobadilla) and other casuistic tratados. Demonstrating the importance of circumstance and narrative economy, of wisdom derived from experience and of properly knowing oneself (nosce te ipsum), Sancho embodies many traits of the ideal ruler, even as he improvises in his own inimical manner.
\end{abstract}

\section{Keywords}

Sancho Panza - Barataria - statecraft - casuistry - novelistic character

Although casuistry in Cervantes has been discussed primarily in relation to his theatrical works, ${ }^{1}$ recent studies of legal and political discourse in Don Quijote $^{2}$ bring casuistry to the fore in Cervantes' engagement with contemporary ideas on statecraft and jurisprudence. While examining the interrelated development of legal and casuistical procedure in early modern Spain, Roberto González Echevarría notes how Don Quijote's questioning of the galeotes (DQ I.22) dramatizes a new aesthetic concerned with circumstances: "This casuistry makes way for the concreteness of the new literature, focused on individuals, specific events, objects, and settings, spurning not just received literary but also philosophical traditions" (33). Contending that this "new literature" is inimical to allegorical readings, to abstractions, González Echevarría

1 Hilaire Kallendorf suggests that Cervantes favored the Jesuit educational program, as evidenced in the festive scene of Berganza playing with the students in El coloquio de los perros (Kallendorf 25-6). Luis Gómez Canseco demonstrates the importance of probabilism in $L a$ gran sultana, as well as how casuistry is present in Cervantes' theater generally, informing plot structures from exposition to denouement, directing our attention from norm to particular circumstance and the dilemma of decision-making (Gómez Canseco).

2 See Byrne, especially Ch. 3; Cascardi Ch. 3 \& 6. 
is consonant with Borges, who urges us to read Don Quijote not as allegory (or parody, for that matter), but as "la venerable y satisfactoria presentación de una gran persona, pormenorizada a través de doscientos trances, para que lo conozcamos mejor" (2012: 216). ${ }^{3}$ One of the things we learn about our gran persona, according to Borges, is that he is envious of his squire when Sancho Panza is at long last given his governorship. The following pages will focus on what is revealed not about the knight, but rather about Sancho Panza, as he passes through the crucible of the governorship of Barataria.

The present study reveals multiple aspects of casuistry in Don Quijote. One is the general "method of mind" which Henry Sullivan saw as pervasive in the culture of Cervantes' Spain, and which is evidenced in the mode of argumentation in many of the scenes we shall consider. There are also numerous instances in which the confessional casuistry of "examination of conscience" and contemplation of sins is evoked. As we shall see, the most pronounced vein of casuistry in the Barataria episodes is that involving the conscience of the ruler, that is, the casuistry of statecraft.

It is widely acknowledged that the specula principum genre is behind much of the episode, from don Quiote's consejos to the qualities Sancho displays in his actions and judgments. Among the major background texts are Jerónimo Castillo de Bobadilla's Política de corregidores (1597), Pedro de Ribadeneira's Tratado de la religion y las virtudes (1595), and possibly Fadrique Furió Ceriol's El consejo y consejeros del Príncipe (1559). Issues treated in such works, and which are taken up in the Barataria episode, include the bearing and dress of the ruler, his pastimes, promulgation of laws and acknowledgment of local customs, the comparative virtues of severity vs. leniency, and choosing of advisers. ${ }^{4}$ Horacio Chiong Rivero maintains that the Barataria episode offers little in terms of precept that represents any innovation to the long tradition of specula principum literature; but the way Sancho engages with this tradition and, not least, his manner of ultimately taking leave of it, is unprecedented: "la modernidad cervantina radica en la novelización de toda una gama de avisos pragmáticos que distan del objetivo y del tono moralizantes de los tratados políticos" (136). In accordance with Chiong Rivero's emphasis on the particular subjectivity Sancho brings to bear on the conventions of specula principum, I will underline how - with the episode's focus on Sancho's

3 For additional comments on casuistry in Cervantes, see David Mañero Lozano's essay in this volume.

4 A good summary of the scholarship on the sources is offered by Horacio Chiong Rivero, who argues also for the importance of Guevara's Relox de príncipes (1529) as a source. See also Bleznick, Cascardi, Percas de Ponseti, and Fernández Santamaría. 
conscience - the "novelization" of the subject matter owes much to innovations in casuistical thought.

\section{The Tension between Precept and Circumstance: Sancho's refranes}

As the essays in this volume variously discuss, a fundamental quandary addressed by the casuists was the potential inapplicability of existing precept (laws, commandments, prior learned opinion) to particular situations. The confidence of the exemplary tradition in setting forth valid models gives way to a questioning of the models, be it examples of illustrious actions from the past or laws handed down from distant times and places. Even church authorities were re-examined, to the extent that substantive conflicting opinions could be found. ${ }^{5}$ Thus came about the exquisite attention to circumstance, to complex particularities, that is a hallmark of casuistical thought. The novelistic quality of Don Quijote owes much to the nuanced epistemology of casuistry; and Sancho's use of proverbs provides an illustration in miniature.

Along with references to diverse aspects of bodily and animal experience, as well as customary malapropisms, the refranes of Sancho represent linguistic usage that is deeply connected with the identity and lived reality of the speaking subject. While the proverbs may convey a sort of practical, empiricallybased wisdom of the popular classes, Sancho frequently fails to use them coherently - as an exasperated Don Quijote repeatedly points out: "Yo te aseguro que estos refranes te han de llevar un día a la horca; por ellos te han de quitar el gobierno tus vasallos, o ha de haber entre ellos comunidades. Dime, ¿dónde los hallas, ignorante, o cómo los aplicas, mentecato, que para deciryo uno y aplicarlo bien sudo y trabajo como si cavase?" (II. 43 italics added). Even as he sometimes marvels at Sancho's ability to recite multiple proverbs with the slightest pretext, Don Quijote rightly points out that it is quite another thing to apply one judiciously. Despite the proverb's claim to reveal general truths about the ways of the world, Don Quijote observes that there is still some contingency, one must correctly consider the present circumstances, and judge whether they are sufficiently analogous to the proverb. And, as he well expresses, it is hard work to do so. Don Quijote's digging analogy calls to mind the etymology of "exemplum," which, as Lyons has discussed, derives from a "clearing in the woods," and the process of "selecting, framing, and regulating

5 For the background of such "probabilistic" thinking, see Maryks (2016). Sullivan noted how casuistry could provide alternative, ameliorating perspectives for "ordinary people disconcerted by the sternness of religious commandments" (44). 
(that is, subordinating to a rule) some entity or event" (Lyons 3-4). Chosen well, an example may illuminate a present situation, or even serve as guide; indiscriminate use produces mere accumulation, rather than something that is illustrative or persuasive (Lyons 10). Sancho's proverbs frequently fall into this second category, as he himself admits: "sé más refranes que un libro, y viénenseme tantos juntos a la boca cuando hablo, que riñen por salir, unos con otros; pero la lengua va arrojando los primeros que encuentra, aunque no vengan a pelo" (II. 43). As we will see, both the cases in which Sancho errs and those in which he seems to hit the mark provide insight into the casuistical quandary of appealing to the appropriate authorities and precepts when making sense of, as Lyons put it with regard to example, "some entity or event."

\section{Sancho Gobernador: Laws and Adjudication}

Pedro de Ribadeneira's discussion of laws and circumstances, and the importance of good advisers (Tratado de la religion y las virtudes, especially Bk. II. 32-33), is relevant to Sancho's governorship. The primary adviser, of course, is Don Quijote, whose letter to Sancho finds its sources in the specula principum tradition. ${ }^{6}$ And part of his counsel has to do with setting laws:

No hagas muchas pragmáticas; y si las hicieres, procura que sean buenas, y, sobre todo, que se guarden y cumplan; que las pragmáticas que no se guardan, lo mismo es que si no lo fuesen; antes dan a entender que el príncipe que tuvo discreción y autoridad para hacerlas, no tuvo valor para hacer que guardasen. (II. 51)

Ribadeneira had expressed the same idea in the following terms:

[...] el Principe pierde reputacion quando sus leyes no son obedecidas. Y por esso conviene que las leyes sean pocas, y muy miradas [...] Y con razon se llama el Principe ley biva, no solo porque tiene potestad para hazer la ley é interpretarla, y dispensar en ella, sino tambien porque la ley por si es muerta, si el como anima de la ley con su exemplo no le da vida. (II. 32 )

6 See, for example, Percas de Ponseti, who argues that Cervantes parodies some of the commonplaces promoted by Valdés and Guevara (voiced by don Quijote), while remaining in step with contemporary moralists such as Bobadilla and Mariana. 
Susan Byrne has discussed the backdrop of legal chaos and cacophony in Spain during this time as attempts were made to consolidate the various codes and integrate them with local customs to ensure their clear promulgation. Felipe II's Recopilación (1567) refers to this dilemma: "Porque somos informados, que muchas leyes y premáticas que hemos hecho para el buen govierno destos Reynos, no se han guardado; ni guardan" (cited in Byrne 101). Sancho's "Constituciones" echo much contemporary legislation, including the "Recopilación," for example in his prohibition of "cantares lascivos y descompuestos, ni de noche ni de día" (II. 51). ${ }^{7}$

If Sancho's process of selecting and implementing laws, with Don Quijote's guidance, represents a sort of tutiorism, mandating strict punishments for any transgression, other aspects of his governing are in the vein of probabilism, as he displays interest in the nuance and circumstances of the cases before him. In this he is consistent with Ribadeneira, who, given his hard line on the viability of laws ("la ley siempre es la misma é invariable", II. 14) and opposition to freedom of conscience, is sometimes surprisingly sensitive to the complexity of prudent rule. He emphasizes, for example, the importance of listening to the grievances of his vassals; ; and Ribadeneira's art of princely prudence, which cannot be gained by blind adherence to rules, produces the following probabilistic discourse: "por ser tantos los particulares, y tantas y tan varias las circunstancias que el verdadero prudente deve considerar en sus acciones, para acertar, que no se pueden con ningunas reglas comprender" (II. 33).

Castillo de Bobadilla's Política de corregidores (1597) also provides some of the blueprint for Sancho's governorship. As Benjamín González Alonso notes in the preliminary study to his edition, Castillo de Bobadilla's mode of thought owes much to scholasticism and casuistry: the truth is there to be found in the existing authorities, but the intellectual endeavor consists of interpreting these existing truths, illustrating them in concrete cases (Castillo de Bobadilla 23). ${ }^{9}$ The Second Book of Politica de corregidores contains a striking number of parallels with Sancho's administration of Barataria. Sancho coincides with

7 See Jean-Marc Pelorson's commentary to the chapter, note 3/39, in https://cvc.cervantes.es/ literatura/clasicos/quijote/edicion/parte2/cap51/cap51_o3.htm.

8 "Porque cuando no se oyen las justas quexas de los vassallos contra los Governadores, de mas de cargo de la conciencia, los mismos Governadores se hazen mas absolutos, y los vassallos viendo que no son desgraviados no oydos, entran en desesperacion" (Ribadeneira II. 32).

9 Among others, Percas de Ponseti has noted the relevance of Castillo de Bobabilla to the Barataria episode. While noting Castillo de Bobadilla's discussion of cases in which a corregidor may contravene laws, Byrne points out the casuistical slippery slope that can result: "he notes six specific reasons that allow a corregidor to go against the law with impunity in a broad sense (II.10.69-76, 1:386-7). Additionally, after each general rule duly noted, this magistrate lists the multiple doubts, occasions, amplifications, and limitations that contradict its stipulations" (48). 
Castillo de Bobadilla in his critique of excessive leisure (both illustrate their argument incorporating the emblem of the industrious bee), the importance of curtailing vagrancy and promoting productive labor, of gambling reform, and in his recommendation that the governor involve himself in the disputes and conflicts of his subjects ("conviene interponerse en questiones y renzillas", Castillo de Bobadilla II. 45). Sancho's critique of the excesses of the Duke and Duchess's dedication to the hunt resonates with Castillo de Bobadilla's censure of idle nobility who do not set forth positive examples for the lower estates; and Sancho performs the sort of hunt advocated in Política de corregidores, the "caça nocturna": "Conviene pues, que el Corregidor ronde, y sus Oficiales no duerman y que todos velen, e esten en centinela" (II. 8).

The first renzilla encountered by Sancho and his ministers as they perform the rounds are two men who have emerged from a gambling den, and whose dispute has escalated to a physical altercation. They are commanded to explain themselves so that Sancho may consider the case. The response of the first man, an onlooker who had helped the other during his winning run at cards, abounds in casuistical discourse: he heeds dictates of narrative economy ("le diré con toda brevedad") - a point to which we will return -, refers to more than one "suerte dudosa" (or dispute), during which he advocated for the other man, and refers twice to conscience: "contra todo aquello que me dictaba la conciencia"; "qué poca vergüenza y qué poca conciencia!" (II. 49). After listening to the counterclaim, Sancho touches upon the casuistry of gambling gains ("vos, ganancioso, bueno, o malo, o indiferente"), summarizes the circumstances of each claimant, and provides a nuanced if firm judgment, tailoring a punishment to each one of them and simultaneously addressing social needs:

[...] dad luego a este vuestro acuchillado cien reales, y más habéis de desembolsar treinta para los pobres de la cárcel; y vos, que no tenéis oficio ni beneficio, y andáis en nones en esta ínsula, tomad luego esos cien reales y mañana en todo el día salid desta ínsula desterrado por diez años. (II. 49)

When he then declares his intention to get rid of the gambling dens, he learns a lesson about political power as well as gradations of vice. As the escribano observes, the power of the social elite stands in the way: "Esta, a lo menos (...) no la podrá vuesa merced quitar, porque la tiene un gran personaje” (II. 49). But the proposed compromise also involves accepting the impossibility of eradicating gambling, and mitigating the damages by proscribing the activity within more orderly paramaters: "y pues el vicio del juego se ha vuelto en ejercicio común, mejor es que se juegue en casas principales que en la de algún oficial" (II. 49). Again, the source here could very well be Castillo de Bobadilla, 
who, despite conventional moralizing against el juego, makes a concession "en algunas casas principales (...) donde suelen juntarse a jugar, mas por via de entretenimiento y conversacion, que a juegos rezios" (II. 21). Sancho seems to accept the reality, which also involves adapting to social custom ("se ha vuelto en ejercicio común"), and the incident ends with a typically Cervantine inconclusiveness: "Agora, Escribano - dijo Sancho -, yo sé que hay mucho que decir en eso" (II.49). ${ }^{10}$

The case of the "forastero" is also shot through with casuistical discourse. It is a folkloric paradox tale, consisting of a bridge on which each traveler must truthfully state his destination and purpose, and the penalty for lying is the gallows; but what to do with the man who swears he has come to be hanged? (II. 51). The term caso returns repeatedly, as well as the modifiers dudoso and dificultoso, as Sancho contemplates how to apply positive law ("ley rigurosa"). When Sancho opts for clemency, even though rewarding the man's honesty by letting the man live would render him a "liar," he says he is merely following the precept given to him by Don Quijote ("Si acaso doblares la vara de la justicia, no sea con el peso de la dádiva, sino con el de la misericordia" II. 43). The principle of clemency in cases of doubt is also recommended by Ribadeneira (Tratado II. 12).

Other cases solved by Sancho have similarly folkloric, riddle-solving qualities. The relevance of casuistry to them resides in the application of precept and reason to clarify dilemmas. In addition to relying on general principles (e.g. clemency) to guide him, Sancho draws upon his own particular epistemology, which proves effective. The empirical emphasis of Furió Ceriol, who values

10 For more on this episode in the context of contemporary (very casuistical) debates on gambling, see Scham (190-200). For the casuistical background of the category "indiferente," see Jonsen and Toulmin, Ch. 3 and Ch. 7. The Jesuit Antonio Escóbar y Mendoza uses the concept in relation to go-betweens and pimps (alcahuetes), for example in his discussion of the role of the servant (criado), providing us, as with so many of the casos recorded in these compendia, illustrations of early modern life and rituals: "Aparejar el cavallo en que ha de yr el amo a casa de la amiga, hazerle espaldas para guardarle, poner a la amiga la mesa, guisar la comida, llevarla a casa, llevarla papeles no deshonestos, aunque si de alguna aficion, y mas que ordinaria cortesia, ministrar regalos, abrir puerta, o ventana, mostrar donde esta su amo a la amiga, darle el pie, tener la escala" (Examen y practica de confessores y penitentes, I.40). If this puts us in mind of Pármeno and Sempronio's service of love-sick Calisto (see Marlen Bidwell-Steiner's essay on La Celestina in this volume), it also reminds us that Don Quijote gave a spirited defense of alcahuetes during his discussion with the galley slaves (Don Quijote I. 22). Though the entire scene, with its euphemisms and double-talking scoundrels, presents an ironic mundo al revés, it is worth noting that Don Quijote makes the same point as Sancho's page regarding gambling: "que no le debía ejercer sino gente muy bien nacida" (II. 22). Both inclinations are seemingly impossible to eradicate; better to "civilize" them through upper-class administration. For the casuistical quality of the entire galeote scene, see González Echevarría. 
practical knowledge and is suspicious of abstract speculation and conjecture, can be seen in Sancho's solution to the case of the cane and the lent/stolen money. Furió Ceriol's observation of the "razonable memoria" of "sanguinos" (86) seems also to apply to Sancho. Noticing the transfer of the cane when the defendant swears he has returned the money to the claimant, Sancho solves the deceptive oath by having the cane broken to reveal the gold coins inside. Sancho's shrewd observation is aided by his memory of a similar case, represented by his own sort of church authority - the sermon of a country priest: "que él había oído contar otro caso como aquel al cura de su lugar" (II. 45).

An oath is sworn also by the man accused of violating the rustic "dueña" in the following case: "Dice que la forcé, y miente, para el juramento que hago y pienso hacer; y esta es toda la verdad, sin faltar meaja" (II. 45). This oath turns out to be true, as Sancho confirms by having the man give the woman his pouch of coins, and then telling him to recover it. The impossibility of the endeavor allows Sancho to judge the case conclusively: "si el mismo aliento y valor que habéis mostrado para defender esta bolsa le mostrárades, y aun la mitad menos, para defender vuestro cuerpo, las fuerzas de Hércules no os hicieran fuerza" (II. 45). A probable source for this is fray Francisco de Osuna's Norte de los estados (Seville 1531), a homiletic, practical guide to conjugal life that has much in common with the various manuales for priests and penitents circulating in the period. ${ }^{11}$ If such guides were gaining wider audiences by being written increasingly in the vernacular rather than Latin, Sancho's recollection of the priest's sermon suggests that they also permeate oral culture.

The most casuistical of the cases Sancho judges during his rounds is that of the disguised young boy and his sister, who had escaped paternal confinement. In contrast to the other cases with their folkloric and homiletic source material, these characters and their circumstances are decidedly more novelistic. As such, they also present a greater challenge to Sancho's attempt to impose order and meaning. The discovery of the young girl dressed as a boy causes general confusion, because unlike the other cases brought before him, this one is not staged by the Duke and Duchess' minions: "porque aquel suceso y hallazgo no venía ordenado por ellos" (II. 49). It thus represents a sort of unruly reality imposing itself upon the artifice and theatricality of Sancho's court. And the casuistical discourse is present from the outset: "estaban dudosos, esperando en qué pararía el caso; Sancho quedó pasmado de la hermosura de la moza, y preguntóle quién era, adónde iba y qué ocasión le había movido para vestirse en aquel hábito" (II. 49). Sancho sets about investigating the "doubtful case" by deploying a good part of the hexámetro used by confessors: Quien, que, donde,

11 See Don Quijote, eds. Morales and Soriano 1319, n. 3. For a discussion of the proliferation of such manuals, as well as an illustrative list, see O'Banion, especially 338 . 
con que, porque, como, quando..$^{12}$ Among the other nuances of circumstance, the casuists strove to take into account factors such as the age, sex, social class, intention and state of mind of the person in question. These details are all duly obtained: the flustered ("turbada") young girl, daughter of the "hidalgo principal y rico" Diego de la Llana, has escaped her widower father's confinement in order to satisfy her curiosity about the world. Her transgression is having contravened "el decoro que a la honestidad se debe" (II. 49). Interestingly, a full explanation of the "sin" is not given until a sort of private space has been established, thereby increasing the confessional character of the scene: "Haga (...) apartar la gente, porque esta señora con menos empacho pueda decir lo que quisiere" (II. 49).

The girl proceeds to give an account of her case ("Es el caso ..."), explaining the father's confinement of the two siblings following their mother's death and her growing desire to see the world and its varied entertainments ("toros," "cañas," "comedias"), as related by her brother. The narration is interrupted by fits of sobbing. Her brother is then questioned separately, and his account corroborates that of his sister. The episode contains a range of assertions, motives, reactions and judgments that do not always cohere, and that reveal Sancho and his entourage (Mayordomo, Maestresala and Secretario) to be both skillful and flawed assessors of the case before them. The reality of the girl's situation ultimately escapes their comprehension, for reasons the casuists well understood.

After listening to the full account of the girl, Sancho's reaction reveals some insight into narrative efficiency:

[...] para contar esta necedad y atrevimiento no eran menester tantas largas ni tantas lágrimas y suspiros; que con decir: "Somos fulano y fulana, que nos salimos a espaciar de casa de nuestros padres con esta invención, sólo por curiosidad, sin otro designio alguno", se acabara el cuento, y no gemidicos, y lloramicos, y darle. (II. 49)

The girl agrees, attributing the narrative disorder and excess to her agitated state ("la turbación que he tenido ha sido tanta, que no me ha dejado guardar el término que debía" [II. 49]). Sancho's words echo the advice in casuistry manuals for efficient confession. In his "cuatro reglas para declarar las circunstancias," Bartolomé de Medina stipulates that details to be included are those that might alter the type of $\sin$ ("cuando mudan especie de pecado"), or potentially aggravating circumstances ("cuando agravan el pecado"); superfluous information - whether an act was committed before or after lunch, for 
example -, or information implicit in the act - the caresses and kisses during coition -, may be omitted (Breve instrucción de como se ha de administrar el Sacramento de la penitencia Ch. 9). The excess Sancho criticizes in the girl's account ("lágrimas y suspiros [...] gemidicos, lloramicos") seems to refer not only to her sobbing delivery, but also to how it affects the form and content of her story, and especially, as Sancho comments, insofar as it impedes concision. ${ }^{13}$

But does Sancho's summary get to the heart of the matter? He does seem to acknowledge the mitigating circumstances of the transgression, attributing to the siblings' disobedience and break with decorum a benign motive: "sólo por curiosidad, sin otro designio alguno" (II. 49). Of course, curiosidad is far from a simple notion in Cervantes. It is the engine of the disastrous (and casuistical) experiment in the interpolated "El curioso impertinente" (I. 33-35). In its full sense of both seeking out new knowledge and of doing something with great care, it characterizes the creative impulse itself in the prologue to the Novelas ejemplares: "por esto se cultiva, con curiosidad, los jardines" (80). Cervantes clearly portrays the girl's curiosity in a capacious sense, both as temptation that can lead to sin, but also as an imaginative incitement leading to creative costumes and sallying forth in the world (another variation, in miniature, of the work's principle theme). To return to the moral overtones, it is worth considering Azpilcueta's assessment:

Curiosidad es querer saber sobrado, o desrazonablemente, Lo qual siempre es pecado venial, ora se quiera saber assi por alguno de los cinco sentidos exteriores, ora por alguno interior, o por el entendimiento: porque es contraria a la virtud de la estudiosidad, y contra la razón. ${ }^{14}$

Manual de confessores y penitentes, fol. 248

13 To appreciate the development in his understanding of narrative economy, recall Sancho's tale about the shepherd conveying his flock of sheep across a river, which elicits the following exasperated response from Don Quijote: “ ¿Tan de esencia de la historia es saber las cabras que han pasado, por estenso, que si se yerra una del número no puedes seguir adelante con la historia?" (I. 2O).

14 See also Francisco de Toledo: "Es desordenado apetito de saber ... cosas [que] no pertenecen al que aprende. Y la estudiosidad quebranta el apetito de saber, y esta estudiosidad de tal manera refrena el apetito de saber, que haze que el hombre no quiera saber contra la razon ni dexe de saber las cosas que son necessarias conforme a ella [...] [N]o solo el conocimiento que se haze por el entendimiento, sino tambien por la imaginacion, y por los sentidos exteriores, conviene a saber, vista, oydo, \&c." (Instruccion de sacerdotes, 1596, Cap. XII). Martínez Mata notes the word's shadings in different contexts, from "knowing" ("curioso lector") to "careful," "diligent" (the "curiosos" "ingenios de la Mancha"). Cf. Scham 338, n. 64 . 
This seems to capture important aspects of the girl's curiosity, which involves both her senses and her imagination (in the interior space of her enforced enclosure), as well as Sancho's assessment that it is a venial transgression. The interesting notion that curiosity is inimical to "estudiosidad" seems to refer to its distraction of the mind, carrying it away from matters pertinent to the particular field of study. In the present case, it has distracted her from maintaining decorum as a young girl and daughter of a rich hidalgo. We will see, however, that such a definition of curiosity does not fully capture the motives of the two youth.

In comments that echo contemporary moralists' objections to reading imaginative literature, Bartolomé de Medina alerts confessors to the precariousness of hearing such cases, especially those of young women: "que muchas vezes estos tales [confesores] por hablar con ellas, sienten ciertas titilaciones y humedades sin quererlo" (Ch. 13, fol. 256). As Sancho, the Mayordomo, Maestresala and Secretario have taken the girl aside to hear her confession/ deposition, the effects feared by Medina are evident in the Maestresala:

[...] parecióle que no eran lágrimas las que lloraba, sino aljófar o rocío de los prados, y aun las subía de punto y las llegaba a perlas orientales, y estaba deseando que su desgracia no fuese tanta como daban a entender los indicios de su llanto. (II. 49)

This reaction comes just as the girl had spoken of her own "mal colocados deseos" (II. 49). As it turns out, she seems to realize the levity of her transgression, and the continuation of her account does undercut initial expectations of a grave "desgracia": "No me ha sucedido nada, ni me sacaron celos, sino solo el deseo de ver el mundo, que no se extendía más a ver las calles de este lugar" (II. 49). In fact, she expressly contradicts her earlier claim to violate the decorum of her condition (see above): "pareciéndome que este deseo no iba contra el buen decoro que las doncellas principales deben guardar a si mesmas" (II. 49 italics added). The effect of the siblings on Sancho's entourage, however, instills in the Maestresala a determination to take the girl as his wife, and Sancho to marry the boy to his daughter. The "mal colocados deseos" may better apply to the confessors than the penitents in this case.

Even though Sancho does seem to grasp the import of the girl's account, and is merciful in his judgement, his final reversion to proverbs reveals a failure fully to grasp her situation:

Y de aquí en adelante, no se muestren tan niños, ni tan deseosos de ver el mundo; que la doncella honrada, la pierna quebrada, y en casa; y la mujer 
y la gallina, por andar se pierden aína; y la que es deseosa de ver, también tiene deseo de ser vista. No digo más. (II. 49)

Sancho's attempt to encapsulate the girl's situation with proverbs and commonplaces does not correspond well to the reality of her plight brought on by the excessive measures of a mourning father who has deprived her of the world. In this sense, Sancho's formulations are similar to the partial and unsatisfactory assessments of the "shepherds" who complain of the "bella ingrata" Marcela (I.14), or the halting exemplarity of the multiple explanations given at the end of "El celoso extremeño" (Novelas ejemplares)..$^{15}$ His attempt at terse conclusion, "no digo más," stands in contrast to his acknowledgment of the complexity of the situation with gambling houses: "yo sé que hay mucho que decir en eso" (see above). For a moment, Sancho seems to revert to the injudicious application of proverbs Don Quijote had warned against earlier. But if Sancho's return to proverbs indicates a misapplication of precept, his ultimate decision to leave the governorship reveals, as we shall consider below, the emergence of a fuller understanding.

\section{Sancho as Statesman: Conscience, Intention, Self-Knowledge}

As we have suggested, the workings of casuistry are to be found throughout Don Quijote. In addition to the above-mentioned questioning of the circumstances of the galeotes' crimes (I.22), the interpolated tale of the "Curioso impertinente" is casuistical in exposition, as Anselmo calls upon his good friend for counsel in deciding how and whether to act upon his anxiety regarding his wife's virtue. The story also has clear roots in the literatura sapiencial tradition, hearkening back to the exhaustive interrogation of female chastity in the thirteenth-century Sendebar. Recounting Don Quijote's penitencia in the Sierra Morena to the barber and the priest, Sancho reacts apprehensively to the suggestion that his master might become an archbishop, upon which the barber consoles him in the following terms: "No tengáis pena, Sancho amigo [...], que aquí rogaremos a vuestro amo, y se lo aconsejaremos y aun se lo pondremos en caso de conciencia, que sea emperador y no arzobispo" (I.26). ${ }^{16}$

15 "[...]que quede en el mundo por ejemplo, si no de bondad, al menos de simplicidad jamás oída ni vista” (456). "[...] ejemplo y espejo de lo poco que hay que fiar de llaves, tornos y paredes cuando queda la voluntad libre; y de lo menos que hay que confiar de verdes y pocos años, si les andan al oído exhortaciones destas dueñas de monjil negro y tendido, y tocas blancas y luengas" ( 458 italics added).

16 Cited in Gómez Canseco, note 5. 
The passage prefigures the Barataria episodes in many ways. Sancho's concern with a religious appointment stems from his own marital status and lack of religious training, making him less suited for an ecclesiastical position than for the governorship to which he aspires. The notion of penitence also returns during Barataria, not in the form of amorous suffering (as is the case with Don Quijote in Sierra Morena), but rather with the dietary restrictions imposed by the stern doctor Pedro Recio, as Sancho bitterly complains in his letter to Don Quijote: "he venido a hacer penitencia, como si fuera ermitaño, y como no la hago de mi voluntad, pienso que al cabo al cabo me ha de llevar el diablo" (II. 51). During the earlier scene, the priest and barber judge that Sancho's belief in Don Quijote's fictions is not pernicious: "No quisieron cansarse en sacarle del error en que estaba, pareciéndoles que, pues no le dañaba la conciencia, mejor era dejarle en él, y a ellos les sería de más gusto oír sus necedades" (I. 26). The casuist's concern with conscience offers a perfunctory justification for what is of greater interest: the pleasure provided by hearing Sancho's stories. This entire interplay of confessional register ("error," "conciencia," "penitencia"), narrative efficacy and pleasure intensifies during Sancho's governorship; and it contributes to a final act of reflection that produces a remarkable desenlace.

Chiong Rivero, James Iffland and Agustin Redondo have all argued that much of the episode's transgressive force stems from who this thoughtful statesman is: as Redondo put it, "antítesis de un aristocrático, digno y grave gobernador" (1978: 56). In addition to eliciting festive laughter, the carnivalesque peasant governor takes on an unexpected dignity, which enhances the implied critique of the conventional ruling class (Redondo 1978: esp. 65-67). Alban Forcione emphasized Sancho's creative and ethical development through his narrative atop Clavileño (II. 41) and through the course of his governorship. In like manner, Redondo, deploying terminology of myth analysis, traces Sancho's rise from "helper" to "substitute for the hero," a process that culminates in the Barataria scene (Redondo 2019).

It is worth emphasizing again that Sancho's success as governor does not completely arise ex nihilo. The contemporary debates regarding statecraft articulated criteria that correspond to fundamental aspects of Don Quijote's squire. As the Spanish tratadistas strove to reject the "godless Machiavelli" while still acknowledging the possibility of a "science" of politics and a legitimate Reason of State, they placed a heightened value on empiricism and liberation from abstract and antiquated rules. ${ }^{17}$ As opposed to book learning and theoretical

17 For the general obligation to reject Machiavelli in Counter-Reformation Spain, coupled with the compelling appeal of many of his ideas, see Tierno Galván (1949) and Fernández Santamaría (1980). 
sophistication, sound natural reason on the foundation of life experience is needed to confront a complex and shifting reality. Consistent with probabilism's resistance to strict adherence to precept and majority opinion, such currents of thought give a plausibility to Sancho's fitness as governor, carnivalesque though it may be. According to Phillip II's secretary, Antonio Pérez, a representative of the "realist" and "empiricist" branch of Spanish political thinkers, a corollary to the good governor is not the schoolman, but the "shepherd, farmer, merchant, mariner: all combine nature and experience to ply their trades" (Fernández Santamaría 377). Citing the Centellas de varios conceptos (1614) of the empiricist Catalán Joaquín Setanti, Fernández-Santamaría illustrates the degree to which the casuist method had made its way from the confessional to the court: "The difficult art of ruling thas no sure reglas to serve as its foundation. Instead, what rules it has can be changed by time, circumstance (ocasiones) and the practical mind (entendimientos prácticos) of the statesmen"' (377). Referring to the "art of narrating" (rather than the art of ruling), another of Cervantes' transcendent "low" characters, the dog Berganza makes a similar observation: "Pero ahora no van las cosas por el tenor y rigor de las antiguas; hoy se hace una ley y mañana se rompe, y quizá conviene que así sea" ("Coloquio de los perros" 679). And Julio Caro Baroja, critiquing Pascal's caricature of casuistry as expedience and laxism, counters that the complexity of real life calls for such an approach: "el casuista laxo se pone ante realidades de la vida" (534).

Some of the considerations touched upon above emerge already in the scenes anticipating Sancho's assumption of his post. During the Duchess' questioning of Sancho about the dudas she has regarding Dulcinea's enchantment (not least whether Sancho ever actually saw her) and his fitness for the governorship, the word "escrúpulo" is uttered three times. And Sancho summarizes his plight in the following terms:

Y si vuestra altanería no quisiere que se me dé el prometido gobierno, de menos me hizo Dios, y podría ser que el no dármele redundase en mi conciencia; que maguera tonto, se me entiende aquel refrán de "por su mal, le nacieron alas a la hormiga"; y aun podría ser que se fuese más aina Sancho escudero al cielo, que no Sancho gobernador. (II. 33)

The casuistical register ("dudas," "escrúpulos," "conciencia") emerges as Sancho explains his deception, justifies his relationship to Don Quiote, and, in a prefiguration of his great nosce te ipsum at the end of his reign, reflects upon his identity and the prospects of taking the mantle as governor. In addition to this appeal to the interiority of conscience and subjectivity, and to the 
circumstances and character traits which bind him to his master ("somos de un mismo lugar; he comido su pan; quiérole bien; es agradecido; dióme sus pollinos, y, sobre todo, yo soy fiel"), the following chapter, in which Sancho discusses hunting with the Duke, reveals a consistent casuistical discourse, and one that is instrumental in the development of Sancho's character.

The Duke's advocacy of the hunt is consistent with contemporary treatises on recreation and statecraft: "La caza es una imagen de la guerra [...] agilítanse los miembros del que la usa [...]" (II. 34). Ribadeneira promotes hunting along with sword-play, swimming, and other vigorous physical activities as of particular utility to the martial preparation and exemplary bearing of the upper classes (II. 43). Sancho's governorship hews in large part to the Counter-Reformation, anti-Machiavellian tenor of Ribadeneira, who insists on the primacy of the Catholic character of the ruler (as well as his advisers). In contrast with the tainted sophistication of the politicos, who promote duplicitous simulación and the instrumentalization of religion as a means to retain power, authentic piety cultivates a "razon natural: la qual, si con los vicios y passiones no se escurece, podra mostrar este camino á los Reyes, y alumbrarlos, y guiarlos" (Ribadeneira I. 13). In a chapter extolling peasants, Ribadeneira praises not only their productive cultivation of natural resources, but also virtues that arise from close contact with the earth - for example, a particular fitness for martial duty: "el labrador puede tomar las armas mejor que el mercader; y passar los trabajos de la milicia [...] y dormir en el suelo, porque esta curtido y hecho á ello: y como no tiene otros thesoros, ni otras riquezas, sino las que le da la tierra, pelea por ella" (II. 11). Sancho's declaration of purpose as he sets out upon the nocturnal rounds (ronda) of his realm summarizes well his affinity with such thinkers: "Pienso favorecer a los labradores, guardar sus preeminencias a los hidalgos, premiar a los virtuosos y, sobre todo, tener respeto a la religión y a la honra de los religiosos" (II. 49).

Furió Ceriol also held forth qualities of rulers and advisers that would seem to legitimize the rise of someone like Sancho Panza, including praise of the practical knowledge of laborers. But rather than the religious and providential associations of Ribadeneira's "natural reason" (producing a sort of Erasmian holy fool), Furió Ceriol subscribes to humoral theory - and, more importantly, to sound knowledge based on practical experience. He thus favors "esperiencia" over "conjetura," and promotes the following humors:

[...] o sanguino, o colérico, i no de otra complissión; por que los desta mescla i temperamento son ingeniosos, tienen razonable memoria, saben hazer discurso, tienen claro juizio, son justos, amorosos, afables, leales, benéficos, maníficos, manánimos i fuertes de su natural. (86) 
Then again, his appearance should not inspire laughter ("que no cause risa su apariencia" 121), a stipulation Don Quijote seems to appreciate when he advises his squire on his grooming and presentation at court (II. 43). ${ }^{18}$

In further discussions with the Duke following the revelations during the Clavileño episode, Sancho expresses the piety, virtuous intentions and telluric values recommended by Ribadeneira:

[...] venga esa ínsula; que yo pugnaré por ser tal gobernador, que, a pesar de bellacos, me vaya al cielo; y esto no es por codicia que yo tenga de salir de mis casillas ni de levantarme a mayores, sino por el deseo que tengo de probar a qué sabe el ser gobernador. [...] Yo imagino que es bueno mandar, aunque sea a un hato de ganado. (II. 42)

And prior to receiving the famous consejos from Don Quijote, Sancho lays claim to just the type of razon natural described by Ribadeneira: "Letras [...], pocas tengo, porque aún no sé el abecé; pero básteme tener el Christus en la memoria para ser buen gobernador. De las armas manejaré las que me dieren, hasta caer, y Dios delante" (II. 42).

Returning to his response to the Duke's advocacy of the hunt, we see that Sancho's critique of the sport combines logical reasoning with an affirmative awareness of his identity. ${ }^{19} \mathrm{He}$ reasonably points out the folly of exposing rulers to unnecessary risk in pursuit of big game, the cruelty of killing an "innocent" being ("matar a un animal que no ha cometido delito alguno"), and the frivolous time expenditure: "la caza y los pasatiempos más han de ser para los holgazanes que para los gobernadores" (II. 34). Sancho recognizes the benefits of recreation in moderation, proscribed within limits of time and place: "En lo que yo pienso entretenerme es en jugar al triunfo envidado las pascuas, y a los bolos los domingos y fiestas; que esas cazas ni cazos no dicen con mi condición ni hacen con mi conciencia" (II. 34). ${ }^{20}$ Faced with the Duke's conventional defense of the hunt, Sancho considers his current responsibilities and his own particular character, and ultimately follows his conscience. The

18 Bleznick suggests that both Ribadeneira and Furió Ceriol were familiar to Cervantes. Márquez Villanueva offers a concise account of Sancho's humoral suitability: "los de cerebro húmedo, y de un modo especial los gruesos y panzudos, son dormilones y pacíficos, además de ciclotímicos o temperamentalmente inestables, pero de gran inteligencia práctica, lo cual los vuelve muy aptos para las tareas de gobierno aun si carecen de letras formales" (56-57).

19 On humanist thought behind Sancho's rejection of hunt, see Margaret Greer.

20 For a discussion of Sancho's views vis a vis contemporary thought on the benefits and risks of recreation, see Scham (2014). 
appeal to conscience is combined with the assertion that, although certainty may be impossible, the intention with which one acts is important:

Haya lo que hubiere [...] más vale al que Dios ayuda que al que mucho madruga, y tripas llevan pies, que no pies a tripas; quiero decir que si Dios me ayuda yo hago lo que debo con buena intención, sin duda que gobernaré mejor que un gerifalte. (II. 34)

The reliance on good intention is emphasized in two of the most important casuistical guides of the sixteenth century, Martín de Azpilcueta's Manual de confesores y penitentes (1554) and Bartolomé de Medina's Breve instruction de como se ha de administrar el Sacramento de la Penitencia (1580). Sancho purports to adhere to prudence and virtue in his actions, grounding his judgement in Catholic piety and a humble - if exuberant - knowledge of self: "Vístanme [...] como quisieren; que de cualquier manera que vaya vestido, seré Sancho Panza" (II. 42). ${ }^{21}$

\section{Conclusion}

As Don Quijote asserted while counselling his squire, one of the most difficult achievements is the gaining of self-knowledge: "has de poner los ojos en quien eres, procurando conocerte a ti mismo, que es el más difícil conocimiento que puede imaginarse" (II. 42). The classic nosce te ipsum is also found in Ribadeneira, who maintains that it is particularly challenging for a prince, who must be able to distinguish between false and true friends, dismiss the empty praise of sycophants, and avoid being blinded by pride and amor propio (II. 29, "Como se deve guardar el Principe de los lisongeros"). ${ }^{22}$ Sancho's realization is expressed in his typical idiom:

21 For the "probabilistic" quality of such deliberation - recognizing uncertainty and turning to conscience and intention -, see Jonsen and Toulmin, who note that the Jesuits "approached moral questions in the spirit of Aristotle and Aquinas rather than of Plato and Augustine: the problem that occupied them was how to choose a course of action prudently and virtuously, rather than how to ascend to a vision of eternal truth" (Jonsen and Toulmin 148).

22 Furió Ceriol also stressed the importance of surrounding oneself with people who would speak the unvarnished truth (Ch. 4). The role of authentic friendship in achieving self-knowledge is examined in the tradition of "literatura sapiencial," including Petrus Alfonsi's Disciplina clericalis (see the first dialogue). 
Yo soy del linaje de los Panzas ... Quédense en esta caballeriza las alas de la hormiga, que me levantaron en el aire para que me comiesen vencejos y otros pájaros, y volvámonos a andar por el suelo con pie llano. (II. 53)

If Sancho displays a degree of amor propio here, it is a pride over his humble state. He is, on the one hand, remaining faithful to type. But this reaffirmation of telluric values ("volvamos a andar por el suelo") is all the more notable as it comes after Sancho has achieved his high ambition of governing. As Cascardi put it, the entire sequence, following the lofty perspective atop Clavileño (II. 41), involves "politics brought down to earth;" but this process occurs in the qualified manner we have identified as a hallmark of casuistry: "rather than move us in a seamless fashion from the realm of theory toward the world of practice, these episodes magnify the over-simplification inherent in the very idea of such a progression" (Cascardi 139).

Sancho acquits himself well as governor, but he also experiences the unsavory aspects of life at court, and decides that he prefers his old mode of existence. But this "old" identity is a composite: not only his humble peasant self, but also the escudero, an identity fortified by the friendship and adventure he shares with Don Quijote ("entre alegre y triste venía caminando sobre el rucio a buscar a su amo, cuya compañía le agradaba más que ser gobernador de todas las ínsulas del mundo" II. 54). This awareness of self, gained through experience, brings an ethical development, as displayed in his judgements and in his debate with the Duke regarding the hunt. The overt conceptual content of the episode - drawing, as we have seen, upon contemporary political and religious tracts as well as classical philosophical postulations - is appropriated by Sancho in his own idiosyncratic manner, mixed in with the earthy discourses of oral culture and applied to unexpected and perplexing events. Ortega y Gasset's famous pronouncement that Don Quijote reveals a modern notion of identity - "Yo soy yo y mi circunstancia" - applies to Sancho as well. The circumstances of Barataria and his recent experiences with Don Quijote allow aspects of his persona to express themselves in sometimes surprising ways. And by this point in the novel, Cervantes has imbued us readers with a casuistical "habit of mind." Faced with the peculiar turns taken by characters as central as knight and squire, and from the lowly Maritornes to the "beautiful ingrate" Marcela, to the curate as he pronounces his literary judgements, we find that our initial understanding will most likely undergo modification as we learn more about them. Sancho Panza becomes similarly aware of the complexities of judgement as he realizes his ambition as statesman, and ultimately arrives at a deeper understanding of himself. Following the intricate caso de conciencia that his experience as governor comprises, his new understanding forms the basis for ethical action - and for novelistic development. 


\section{Works Cited}

Alfonsi, Petrus. Die Kunst, Vernünftig zu Leben (Disciplina Clericalis). Trans. Eberhard Hermes. Zürich: Artemis, 1970.

Avalle Arce, Juan B. "La ínsula Barataria: la forma de su relato." Anales De Literatura Española 6 (1988): 33-44.

Azpilcueta, Martín de. Manual de confessores y penitentes (1554). https://bvpb.mcu.es/ es/consulta/registro.do?id=413671.

Bleznick, Donald A. "Don Quijote's Advice to Governor Sancho Panza." Hispania 40.1 (1957): 62-65. Stable URL: https://www.jstor.org/stable/33567o.

Borges, Jorge Luis. "La conducta novelística de Cervantes." El tamaño de mi esperanza/ El idioma de los argentinos. Buenos Aires: Random House Mondadori, 2012.

Byrne, Susan. Law and History in Cervantes' Don Quixote. Toronto: University of Toronto Press, 2012.

Caro Baroja, Julio. “Probabilidades, laxitudes y corrupciones.” Las formas complejas de la vida religiosa: religión, sociedad y carácter en la España de los siglos XVI y XVII. Madrid: Akal, 1978: 517-550.

Cascardi, Anthony J. Cervantes, Literature and the Discourse of Politics. Toronto: University of Toronto Press, 2016.

Castillo de Bobadilla, Jerónimo. Política de corregidores (1597). Ed. Benjamín González Alonso. Madrid: Instituto de Estudios de Administración Local, 1978.

Cervantes Saavedra, Miguel de. El ingenioso hidalgo Don Quijote de la Mancha. Eds. Justo García Soriano y Justo García Morales. Madrid: Aguilar, 1981.

Cervantes Saavedra, Miguel de. Don Quijote de la Mancha. Edición del Instituto Cervantes, dir. Francisco Rico. https://cvc.cervantes.es/literatura/clasicos/quijote/ default.htm.

Cervantes Saavedra, Miguel de. Novelas ejemplares. Ed. Jorge García López. Barcelona: Crítica, 2005.

Corteguera, Luis R. "Sancho Panza Wants an Island: Cervantes and the Politics of Peasant Rulers." Romance Quarterly 52.4 (2005): 261-70.

Chiong Rivero, Horacio. "Insula de buen gobierno: el palimpsesto guevariano en 'las constituciones del gran gobernador Sancho Panza'. Cervantes: Bulletin of the Cervantes Society of America 28.1 (2008): 135-165.

Escobar y Mendoza, Antonio. Examen y practica de confessores y penitentes. Paris: Antonio Bertier, 1665 (53rd edition). вNм R/4273. http://bdh-rd.bne.es/viewer .vm?id=ooooo79368\&page $=1$.

Fernández-Santamaria, José A. "Reason of State and Statecraft in Spain (1595-1640)." Journal of the History of Ideas 41.3 (1980): 355-379.

Forcione, Alban. "Cervantes' Night-Errantry: The Deliverance of the Imagination." Bss 81.4-5 (2004): 451-73. 
Furió Ceriol, Fadrique. El concejo y consejeros del príncipe. Obra completa. Co-directors Henry Mechoulan and Jordi Pérez Durà. Valencia: Ediciones Unesco, 1996.

Gilbert-Santamaria, Donald. "Sancho's 'Insula' and the Politics of Empire." Hispanófila 150 (2007): 15-25. www.jstor.org/stable/43807465.

Gómez Canseco, Luis. "Probabilismo en Cervantes: La gran sultana como caso de conciencia." Criticón 109 (2010): 167-86.

González Echevarría, Roberto. Love and the Law in Cervantes. New Haven: Yale University Press, 2005 .

Greer, Margaret R. "Diana, Venus and Borrowed Dogs: On Hunting in Don Quixote." Cervantes y su mundo (III). Eds. Robert A. Lauer and Kurt Reichenberger. Kassel: Reichenberger, 2005: 201-22.

Iffland, James. De fiestas y aguafiestas: risa, locura e ideología en Cervantes y Avellaneda. Madrid: Iberoamericana, 1999 .

Jonsen, Albert R. and Stephen Toulmin. The Abuse of Casuistry. Berkeley: University of California Press, 1988.

Kallendorf, Hilaire. Conscience on Stage: The Comedia as Casuistry in Early Modern Spain. Toronto: University of Toronto Press, 2007.

Lyons, John D. Exemplum: The Rhetoric of Exemplarity in Early Modern France and Italy. Princeton: Princeton UP, 1989.

Márquez Villanueva, Francisco. Cervantes en letra viva. Barcelona: Reverso Ediciones, 2005 .

Martínez Mata, Emilio. Cervantes comenta el Quijote. Madrid: Cátedra, 2008.

Maryks, Robert A. "Rhetorical Veri-similitudo: Cicero, Probabilism, and Jesuit Casuistry." Traditions of Eloquence: The Jesuits and Modern Rhetorical Studies. Eds. Cinthia Gannett and John C. Brereton. Fordham: University Press, 2016.

Medina, Bartolomé de. Breve instrucción de como se ha de administrar el Sacramento de la penitencia (1580). BNM (R/38567) http://bdh-rd.bne.es/viewer.vm?id=0oooo 66803 \&page $=1$.

O'Banion, Patrick J. “'A Pries Who Appears Good': Manuals of Confession and the Construction of Clerical Identity in Early Modern Spain." Dutch Review of Church History 85 (2005): 333-348.

Ortega y Gasset, José. Meditaciones Del Quijote. Ed. Julián Marias. Madrid: Catedra, 1984.

Percas de Ponseti, Helena. "Los consejos de don Quijote a Sancho." Cervantes and the Renaissance. Ed. Michael D. McGaha. Easton, PA: Juan de la Cuesta, 1980: 194-236.

Quintana Tejera, Luis. "Análisis literario de los consejos que da Don Quijote a Sancho antes de ir a gobernar la ínsula Barataria: segunda parte del Quijote." Espéculo: Revista De Estudios Literarios 34 (2006) [no pagination].

Redondo, Augustin. "Sancho Panza, de ayudante del héroe a sustituto del héroe." $\mathrm{eHu}$ manista/Cervantes 7 (2019): 26o-74. 
Redondo, Augustin. "Tradicion carnavalesca y creacion literaria, del personaje de Sancho Panza al episodio de la insula Barataria en el Quijote." Bulletin Hispanique 8o (1978): 39-70.

Ribadeneira, Pedro de. Tratado de la religion y las virtudes. Madrid: P. Madrigal, 1595. https://bvpb.mcu.es/es/consulta/registro.do?id=417725.

Scham, Michael. Lector Ludens: The Representation of Games and Play in Cervantes. Toronto: University of Toronto Press, 2014.

Sullivan, Henry. "Moral Probabilism and Casuistry in Spain during the Counter Reformation." Tirso de Molina and the Drama of the Counter Reformation. Amsterdam: Rodopi, 1976: 40-51.

Tierno Galván, Enrique. El tacitismo en las doctrinas políticas del siglo de oro español. Murcia: Sucesores de Nogués, 1949.

Toledo, Francisco de. Instruccion de sacerdotes, y suma de casos de conciencia (1616). вNм (U/7263) http://bdh-rd.bne.es/viewer.vm?id=ooooo10529\&page=1. 